\title{
ANALISIS PENGARUH DISTRIBUTED GENERATION (DG) TERHADAP INDEKS KEANDALAN PADA PENYULANG MRA05 BANJARNEGARA
}

\author{
Rizky Catur Bekti ${ }^{*}$, Hermawan, dan Bambang Winardi \\ Departemen Teknik Elektro, Universitas Diponegoro \\ Jl. Prof. Sudharto, SH, kampus UNDIP Tembalang, Semarang 50275, Indonesia \\ ${ }^{*}$ E-mail : rizkycb4@gmail.com
}

\begin{abstract}
Abstrak
Tingkat keandalan pada sistem distribusi dapat dilihat dari frekuensi terjadinya pemutusan beban, lama gangguan yang terjadi, dan waktu untuk pemulihan gangguan. Berdasarkan data dari PT PLN (Persero) Rayon Banjarnegara Penyulang MRA05 memiliki 4 buah DG dan selama tahun 2016 mengalami pemadaman sebanyak 15 kali/tahun, dengan total lama padam 38,68 jam/tahun, hal ini tentunya cukup mengganggu kontinuitas penyaluran energi listrik pada Penyulang MRA05. Berdasarkan permasalahan tersebut pada penelitian ini akan dibahas besarnya indeks keandalan (SAIFI, SAIDI, CAIDI, ENS, AENS) pada penyulang MRA05 saat kondisi DG tidak terpasang dan terpasang. Perhitungan besarnya indeks keandalan dilakukan dengan menggunakan metode Reliability Index Assesment (RIA), selanjutnya hasil perhitungan akan dibandingkan dengan hasil simulasi menggunakan software ETAP 12.6.0 0 Indeks keandalan yang didapat berdasarkan perhitungan menggunakan metode RIA saat kondisi DG tidak terpasang, nilai SAIFI sebesar 2,96228 gangguan/tahun, nilai SAIDI sebesar 9,1185 jam/tahun, nilai CAIDI sebesar 3,078 jam/gangguan, nilai ENS sebesar 42,1842 MWh/tahun, nilai AENS sebesar 0,00358 MWh/pelanggan. Indeks keandalan saat kondisi DG terpasang, nilai SAIFI sebesar 2,96228 gangguan/tahun, nilai SAIDI sebesar 7,567 jam/tahun, nilai CAIDI sebesar 2,5546 jam/gangguan, nilai ENS sebesar 35,11578 MWh/tahun, nilai AENS sebesar 0,0029 MWh/pelanggan.
\end{abstract}

Kata Kunci: Distributed Generation (DG), keandalan, Reliability Index Assesment (RIA), ETAP 12.6.0

\begin{abstract}
Reliability in the distribution system can be seen from the frequency of the interruption, the duration of the interruption, and the time for recovery of the iinterruption. Based on data from PT PLN (Persero) Rayon Banjarnegara Feeder MRA05 has 4 DG and during the year 2016 experienced interruption as $15 \mathrm{f} /$ year, with total duration of 38.68 hours / year, this is quite disturbing continuity of electrical energy distribution in feede MRA05. Based on the problem, this research will discuss the reliability index (SAIFI, SAIDI, CAIDI, ENS, AENS) on feeder MRA05 when DG condition is not installed and installed. Calculation of reliability index using Reliability Index Assessment (RIA), then the calculation result will be compared with simulation result using software ETAP 12.6.0 The reliability index is calculated using RIA method when DG is not installed, , SAIFI value is $2.96228 \mathrm{f} / \mathrm{yr}$, SAIDI value is $9.1185 \mathrm{hr} / \mathrm{yr}$, CAIDI value $3.078 \mathrm{hr} / \mathrm{f}$, ENS value $42.1842 \mathrm{MWh} / \mathrm{yr}$, AENS value $0.00358 \mathrm{MWh} /$ cust . Reliability index when DG is installed, SAIFI value is $2.96228 \mathrm{f} / \mathrm{yr}$, SAIDI value is $7.567 \mathrm{hr} / \mathrm{yr}$, CAIDI value is $2.5546 \mathrm{hr} / \mathrm{f}$, ENS value is 35.11578 $\mathrm{MWh} / \mathrm{yr}$, AENS value is $0.0029 \mathrm{MWh} / \mathrm{cust}$.
\end{abstract}

Keywords: Distributed Generation (DG), Reliability, Reliability Index Assessment (RIA), ETAP 12.6.0

\section{Pendahuluan}

Keandalan merupakan tingkat keberhasilan kinerja suatu sistem atau bagian dari sistemuntuk memberikan hasil yang lebih baik pada periode waktu dan dalam kondisi operasi tertentu[1]. Irfanda dkk [2] menyebutkan bahwa keandalan sistem distribusi dipengaruhi oleh gangguan yang terjadi pada sistem yang menyebabkan pemutusan beban, sehingga berdampak pada kontinuitas ketersediaan pelayanan tenaga listrik ke pelanggan. Keandalan suatu jaringan distribusi dapat dilihat dari besar kecilnya indeks keandalan pada jaringan distribusi tersebut. Indeks keandalan tersebut diantaranya[3]:

- System Average Interruption Frequency Index (SAIFI)

- System Average Interruption Duration Index (SAIDI)

- Customer Average Interruption Duration Index (CAIDI)

- Energy Not Supplied (ENS)

- Average Energy Not Supplied (AENS)

Standar indeks keandalan menurut ketetapan SPLN 68-2 1986 dimana nilai SAIFI sebesar 3,2 kali/tahun dan SAIDI sebesar 21 jam/tahun[4]. Salah satu cara untuk 
menghitung besarnya indeks keandalan pada jaringan distribusi ialah dapat menggunakan metode Reliability Index Assesment (RIA). Secara fungsional metode RIA akan mendata kegagalan yang terjadi pada peralatan secara komperehensif, lalu mengidendifikasi kegagalan tersebut, dan menganalisis mode kegagalan tersebut, sehingga akan dihasilkan indeks-indeks keandalan pada jaringan distribusi tersebut[5].

Penyulang MRA05 GI Mrica Banjarnegara yang pada tahun 2016 mengalami peadaman sebanyak 15 kali, dengan total lama padam 38,68 jam. Sampai dengan tahun 2016 Penyulang MRA05 telah memiliki 4 buah Distributed Generation (DG) dengan jenis Pembangkit Listrik Tenaga Mikrohidro (PTMH), yaitu PLTMH Sigebang 500 KW, PLTMH Kincang 320 KW, PLTMH Adipasir 320 KW, PLTMH Rakit 500 KW. DG didefinisikan sebagai suatu pembangkit dengan kapasitas maksimal berkisar sampai $50 \mathrm{MW}$ dan dipasangkan pada jaringan distribusi[6].Salah satu keuntungan dari adanya DG pada jaringan distribusi adalah DG dapat membantu meningkatkan keandalan pada jaringan distribusi[7].

\section{Metode}

\subsection{Langkah Penelitian}

Langkah-langkah penelitian penelitian ini ditunjukkan pada gambar 1 sebagai berikut.

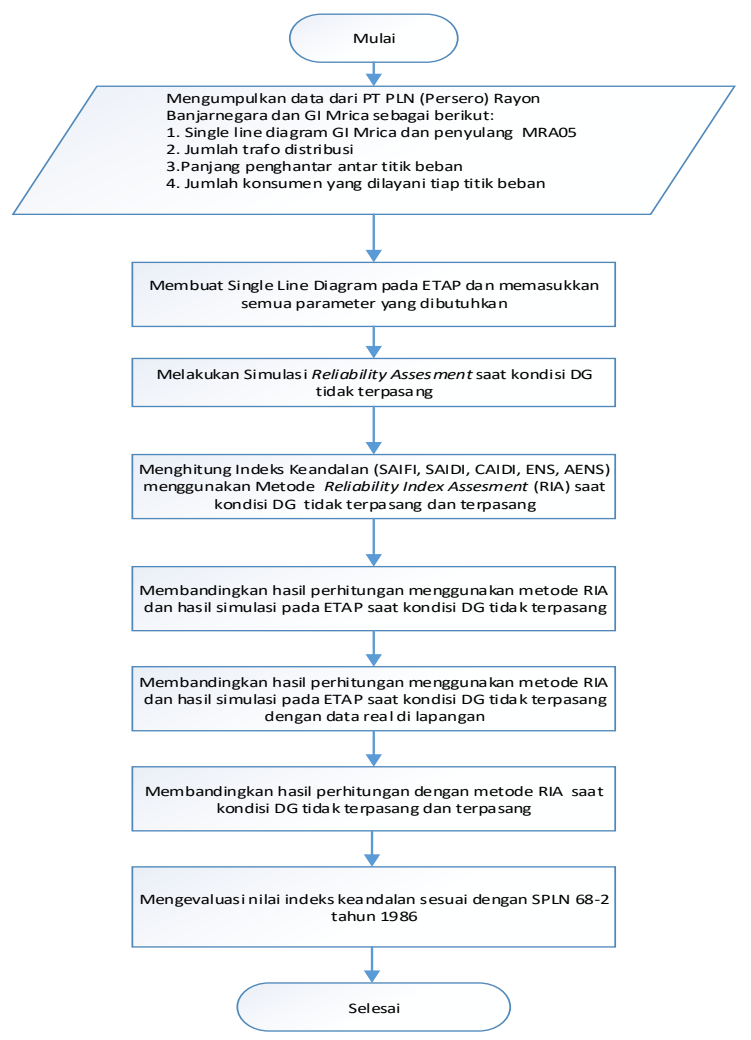

Gambar 1. Bagan Alir Penelitian

\subsection{Pengumpulan Data}

Data-data yang diperlukan dalam penelitian ini diperoleh dari PT. PLN (Persero) Rayon Banjarnegara antara lain single line diagram, data trafo distribusi,data pemadaman pada tahun 2016 dan data pelengkap lainnya. Selain itu terdapat juga data hasil literatur laju kegagalan komponen, dan impedansi penghantar.

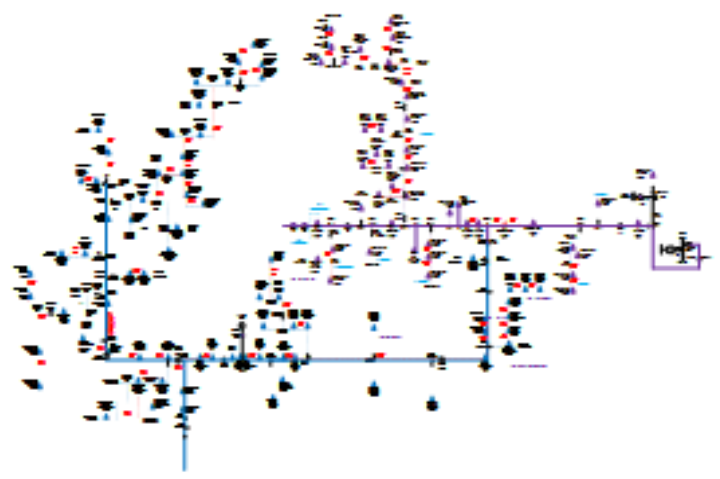

Gambar 2. Single Line Diagram MRA05

Penyebab terjadinya pemadaman sebagian besar disebakan oleh faktor non teknis seperti faktor lingkungan, alam dan faktor non teknis lainnya yaitu sebesar 73,33\%, sedangkan 26,67\% disebkan oleh kegagalan komponen yang ada pada penyulang MRA05.

\subsection{Penggambaran Pada ETAP 12.6.0}

Penggambaran jaringan MRA05 pada ETAP 12.6.0 ditunjukkan pada Gambar 3.

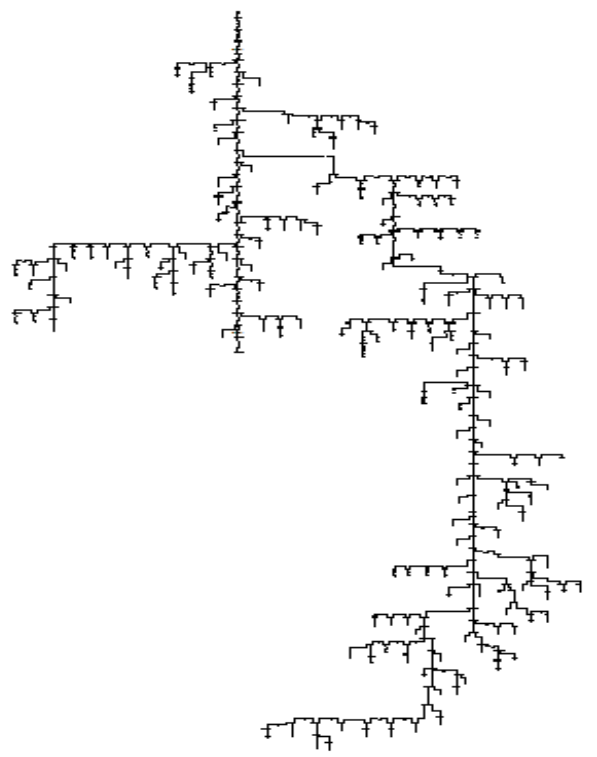

Gambar 3. Penggambaran MRA05 pada ETAP 12.6.0 


\subsection{Simulasi ETAP}

Simulasi untuk menentukan besarnya indeks keandalan menggunakan menu "Reliability Assessment" dengan hasil keluaran pada Reliability Assessmennt Report adalah indeks SAIFI, SAIDI, CAIDI, ENS. dan AENS.

\section{Hasil dan Analisa}

\subsection{Saat Kondisi DG Tidak Terpasang}

Pada kondisi ini diasumsikan ketika terjadi gangguan pada penyulang, maka PMT akan trip , sehingga suplai beban dari substation atau gardu induk ke semua titik beban menjadi putus, maka semua titik beban akan padam.

\subsubsection{Perhitungan Menggunakan Metode RIA}

Indeks keandalan yang akan dihitung menggunakan metode reliability index assesment (RIA) yaitu SAIFI, SAIDI,CAIDI, ENS,AENS pada penyulang MRA05. Berikut adalah perhitungan laju kegagalan dan lama gangguan tahunan pada salah satu titik beban yaitu Bus 3 .

\section{- $\quad$ Laju Kegagalan Bus 3}

Laju kegagalan pada bus 3 dipengaruhi oleh laju kegagalan bus 2, serta laju kegagalan komponen yang menuju bus 3, komponen yang menuju bus 3 adalah 0,25 SUTM dan 1 ABSW. Sehingga laju kegagalan bus 3 dapat dihitung sebagai berikut.

$\lambda_{L P}=\sum_{i=K} \lambda \mathrm{i}$

$\lambda_{3}=\lambda_{2}+0,25 x \lambda_{S U T M}+\lambda_{A B S W}$

$\lambda_{2}=0+0,25 x 0,2+0,003$

$\lambda_{2}=0,053$ gangguan/tahun

\section{- $\quad$ Lama Gangguan Tahunan Bus 3}

Lama gangguan pada bus 3 dipengaruhi oleh lama gangguan bus 2, serta lama gangguan komponen yang menuju bus 3 , komponen yang menuju bus 3 adalah 0,25 SUTM dan 1 ABSW. Sehingga lama gangguan bus 3 dapat dihitung sebagai berikut.

$\mathrm{U}_{\mathrm{i}}=\sum_{i=K} \lambda_{i} x r_{j}$

$\mathrm{U}_{3}=U_{2}+\lambda_{P m t 1} x \operatorname{MTTR}_{\text {pmt } 1}+$

$0,25 \times \lambda_{\text {SUTM }} \times$ MTTR $_{\text {SUTM }}+\lambda_{\text {ABSW }} \times \mathrm{MTTR}_{A B S W}$

$\mathrm{U}_{3}=0+(0,25 \times 0,2 \times 3)+(0,003 \times 10)$

$\mathrm{U}_{3}=0,18 \mathrm{jam} /$ tahun

Hasil perhitungan laju kegagalan dan lama gangguan tahunan diatas direkapitulasi dari seluruh titik beban ditampilkan dalam Tabel 7.

Setelah laju kegagalan, lama gangguan tahunan, Daya pada titik beban $\left(\mathrm{L}_{\mathrm{i}}\right)$ jumlah pelanggan $(\mathrm{N})$ pada setiap titik beban didapatkan, maka selanjutnya dapat dihitung indeks SAIFI ,SAIDI, CAIDI, ENS dan AENS.
Tabel 7. Rekapitulasi Laju Kegagalan dan Lama Gangguan Tahunan Seluruh Titik Beban

\begin{tabular}{clcccc}
\hline No. & Titik Beban & $\boldsymbol{\Lambda}_{\mathrm{i}}$ (f/year) & $\mathbf{U}_{\mathbf{i}}$ (h/year) & $\mathbf{L}_{\mathbf{i}}(\mathbf{K W})$ & $\mathbf{N}$ \\
\hline 1 & Bus 1 & 0 & 0 & 0 & 0 \\
2 & Bus 2 & 0 & 0 & 0 & 0 \\
3 & Bus 3 & 0,053 & 0,18 & 0 & 0 \\
4 & Bus 4 & 0,493 & 1,5 & 0 & 0 \\
5 & Bus 5 & 0,523 & 1,59 & 0 & 0 \\
6 & Load-1 & 0,602 & 1,89 & 41,65 & 65 \\
7 & Load-2 & 0,722 & 2,25 & 41,65 & 47 \\
8 & Load-3 & 0,562 & 1,77 & 41,65 & 65 \\
9 & Load-4 & 0,785 & 2,46 & 41,65 & 141 \\
10 & Load-5 & 0,915 & 2,85 & 41,65 & 120 \\
$\ldots$. & $\ldots .$. & $\ldots .$. & $\ldots .$. & $\ldots$. & $\ldots$. \\
$\ldots$. & $\ldots .$. & $\ldots .$. & $\ldots .$. & $\ldots$. & $\ldots$. \\
149 & Load-143 & 4,9446 & 15,00 & 20,825 & 65 \\
150 & Load-144 & 4,9546 & 15,03 & 41,65 & 65 \\
& TOTAL & & & & 11764 \\
\hline
\end{tabular}

a. System Average Interruption Frequency Index (SAIFI) SAIFI $=\frac{\sum \lambda_{\mathrm{i}} \mathrm{N}_{\mathrm{i}}}{\mathrm{N}_{\mathrm{i}}}$

SAIFI $=\frac{\sum((0 x 0)+(0 \times 0)+\cdots+4,9546)}{11764}$

SAIFI $=2,96228$ gangguan $/$ tahun

b. System Average Interruption Duration Index (SAIDI)

$\begin{aligned} \text { SAIDI } & =\frac{\sum \mathrm{U}_{\mathrm{i}} \mathrm{N}_{\mathrm{i}}}{\mathrm{N}_{\mathrm{i}}} \\ \text { SAIDI } & =\frac{\sum((0 \times 0)+(0 \times 0)+\cdots+(15,03 \times 65))}{11764} \\ \text { SAIDI } & =9,1185 \mathrm{jam} / \text { tahun }\end{aligned}$

c. Customer Average Interruption Durtion index (CAIDI)

$$
\begin{aligned}
\text { CAIDI } & =\frac{\text { SAIDI }}{\text { SAIFI }} \\
& =\frac{9,1185}{2,96228} \\
& =3,078 \text { jam/gangguan }
\end{aligned}
$$

d. Energy Not Supplied (ENS)

$$
\begin{aligned}
& \mathrm{ENS}=\sum L a(i) . U i \\
& \text { ENS }=42184,19 \mathrm{KWh} / \text { tahun } \\
& \text { ENS }=42,1842 \mathrm{MWh} / \text { tahun } \\
& \text { AENS }=\frac{\text { ENS }}{\sum \text { LP }}
\end{aligned}
$$$$
\text { ENS }=\sum 41,65 \times 1,89+41,65 \times 18,11562,25+\cdots+
$$$$
20,825 \times 15+41,65 \times 15,03
$$$$
\text { e. Average Energi Not Supplied (AENS) }
$$ 


$$
\begin{aligned}
\text { AENS } & =\frac{42,1842}{11764} \\
& =0,00358 \mathrm{MWh} / \text { pelanggan }
\end{aligned}
$$

\subsubsection{Hasil Simulasi pada ETAP}

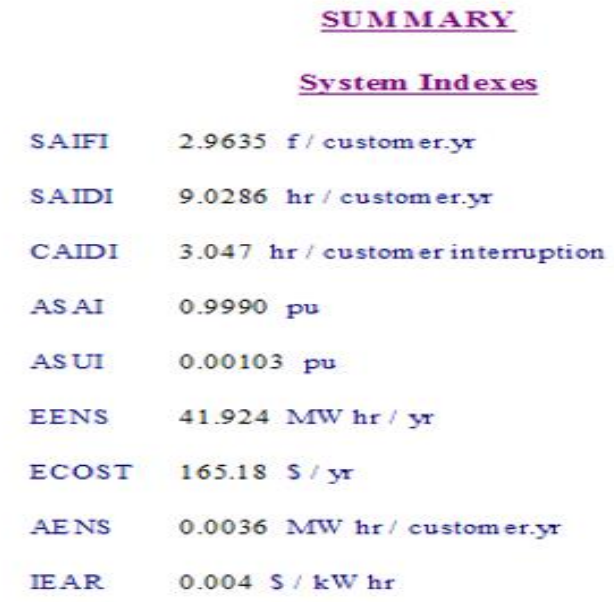

Gambar 4. Indeks Keandalan Hasil Simulasi

Dari Gambar 4 dapat dilihat indeks keandalan penyulang MRA05 dimana nilai SAIFI sebesar 2,9635 gangguan/tahun, nilaia SAIDI sebesar 9,0286 jam/tahun, nilai CAIDI sebesar 3,047 jam/gangguan, nilai ENS sebesar 41,924 MWh/tahun, nilai AENS sebesar 0,0036 MWh/pelanggan.

\subsection{Saat Kondisi DG Terpasang}

Pada kondisi ini diasumsikan saat terjadi gangguan pada penyulang, maka PMT akan trip, sehingga suplai beban dari substation atau Gardu Induk ke titik beban akan putus, namun pada kondisi ini tidak semua titik beban pada penyulang padam. Terdapat beberapa titik beban yang akan segera menyala kembali. Titik beban yang menyala kembali ini disebabkan oleh adanya DG yang dapat beroperasi Islanded system, dengan DG beroperasi islanded system ini maka DG akan bertindak sebagai penyuplai beban pengganti, untuk beroperasi islanded system ini dibutuhkan komponen switching untuk menghubungkan DG ke titik beban dan untuk memisahkan titik beban yang padam dengan titik beban yang akan disuplai oleh DG dengan skenario islanded system ini. DG tidak dapat menyuplai beban pada penyulang secara keseluruhan, DG hanya akan menyuplai beban sesuai dengan titik beban yang ada pada skenario islanded system. Berdasarkan single line diagram pada simulasi ETAP, skenario islanded system dapat dilihat pada tabel 8 .

Dari Tabel 8 dibawah terdapat 2 skenario islanded system. Dari 2 skenario islanded system ini total titik beban yang dapat disuplai sebanyak 28 titik beban. Dengan skenario islanded system ini ketika terjadi gangguan pada penyulang yang menyebabkan PMT trip , sehingga suplai beban dari substation ke titik beban putus, dan menyebabkan semua titik beban padam, maka ke 28 titik beban ini akan segera menyala kembali dengan adanya suplai beban dari DG. Lama gangguan yang dialami ke 28 titik beban ini hanya diantara PMT trip dan DG terhubung ke beban untuk beroperasi islanded system.

\begin{tabular}{|c|c|c|c|}
\hline $\begin{array}{l}\text { Islanded } \\
\text { System }\end{array}$ & DG & Skenario & $\begin{array}{l}\text { Titik beban yang } \\
\text { disuplai }\end{array}$ \\
\hline I & $\begin{array}{l}\text { PLTMH } \\
\text { Sigebang }\end{array}$ & $\begin{array}{l}\text { ABSW } \\
\text { MRA05.05 dan } \\
\text { ABSW } \\
\text { MRA05.061 } \\
\text { dalam kondisi } \\
\text { open }\end{array}$ & $\begin{array}{l}\text { Load 1, Load 2, Load } \\
3\end{array}$ \\
\hline II & $\begin{array}{l}\text { PLTMH } \\
\text { Kincang, } \\
\text { PLTMH } \\
\text { Adipasir, } \\
\text { PLTMH } \\
\text { Rakit }\end{array}$ & $\begin{array}{l}\text { LBS } \\
\text { MRA05.105.s71 } \\
\text { dan ABSW } \\
\text { MRA05.105.S1 } \\
\text { 49.b01 dalam } \\
\text { kondisi open }\end{array}$ & $\begin{array}{l}\text { Load 57, Load 58, } \\
\text { Load 59, Load 129, } \\
\text { Load 130, Load 60, } \\
\text { Load 131, Load 61, } \\
\text { Load 62, Load 63, } \\
\text { Load 64, Load 65, } \\
\text { Load 66, Load 67, } \\
\text { Load 68, Load 69, } \\
\text { Load 70, Load 71, } \\
\text { Load 72, Load 73, } \\
\text { Load 145, Load 74, } \\
\text { Load 75, Load 76, } \\
\text { Load } 77\end{array}$ \\
\hline
\end{tabular}

Tabel 8. Skenario Islanded System

a. System Average Interruption Frequency Index (SAIFI)

Besarnya nilai SAIFI saat DG kondisi terpasang sama dengan besarnya nilai SAIFI saat kondisi DG tidak terpasang, hal ini dikarenakan pada penyulang ini, satu penyulang hanya terdapat satu PMT, sehingga dimanapun terjadi gangguan pada penyulang, maka PMT akan trip dan semua titik beban akan padam. Sehingga adanya DG tidak mempengaruhi nilai SAIFI, oleh karena itu nilai SAIFI saat DG terpasang tetap sama dengan saat DG tidak terpasang, yaitu

$$
\begin{aligned}
& \text { SAIFI }=\frac{\sum \lambda_{\mathrm{i}} \mathrm{N}_{\mathrm{i}}}{\mathrm{N}_{\mathrm{i}}} \\
& \text { SAIFI }=18,1156 \text { gangguan } / \text { tahun }
\end{aligned}
$$

\section{b. System Average Interruption Duration Index (SAIDI)}

Untuk dapat mencari besarnya nilai SAIDI pada penyulang, maka terlebih dahulu mencari lama gangguan pada titik beban pada tabel 8 yang saat DG beroperasi islanded system. karena dengan DG beroperasi islanded system ini menyebabkan titik beban yang seharusnya padam ketika PMT trip menjadi menyala, maka lama gangguan untuk titik beban pada tabel 8 saat DG beroperasi islanded system saya asumsikan menjadi 0 jam/tahun. Sehingga lama gangguan (U) titik beban pada tabel 8 hanya dipengaruhi oleh lama gangguan antara PMT trip dengan DG mulai beroperasi islanded system. keadaan diantara PMT trip dan DG mulai beroperasi 
islanded system ini saya asumsikan adalah waktu yang dibutuhkan untuk komponen switching ( ABSW atau LBS) bekerja untuk mengubungkan DG ke titik beban dan untuk memisahkan daerah yang masuk dalam skenario islanded system dengan daerah yang tidak. Berdasarkan SPLN 59 dapat diketahui lamanya waktu kerja dari saklar pisah adalah sebesar 0,15 jam/tahun [8], Sehingga lama gangguan (U) titik beban yang masuk skenario islanded system pada tabel 8 adalah sebesar 0,15 jam/tahun. Sedangkan lama gangguan (U) untuk titik beban lainnya adalah sama dengan saat kondisi DG tidak terpasang, seperti yang tercantum pada tabel 9 dibawah ini.

Tabel 9. Rekapitulasi Lama Gangguan Tahunan Seluruh Titik Beban saat DG Terpasang

\begin{tabular}{|c|c|c|c|c|}
\hline No. & Titik Beban & $\mathrm{U}_{\mathrm{i}}(\mathrm{h} /$ year) & $\mathrm{L}_{\mathrm{i}}(\mathrm{KW})$ & $\mathbf{N}$ \\
\hline 1 & Load-1 & 0,15 & 41,65 & 65 \\
\hline 2 & Load-2 & 0,15 & 41,65 & 47 \\
\hline 3 & Load-3 & 0,15 & 41,65 & 65 \\
\hline 4 & Load-4 & 2,46 & 41,65 & 141 \\
\hline 5 & Load-5 & 2,85 & 41,65 & 120 \\
\hline$\ldots$ & $\ldots .$. & $\ldots .$. & $\ldots$ & $\ldots$ \\
\hline ... & $\ldots .$. & ...... & $\ldots$ & ...... \\
\hline 144 & Load-143 & 15,00 & 20,825 & 65 \\
\hline 145 & Load-144 & 15,03 & 41,65 & 65 \\
\hline \multicolumn{4}{|c|}{ TOTAL } & 11764 \\
\hline
\end{tabular}

Dari tabel 9 diatas dapat ditentukan indeks rata-rata durasi pemadaman yang dialami pelanggan dalam periode satu tahun (SAIDI) sebagai berikut.

$$
\begin{aligned}
\text { SAIDI } & =\frac{\sum \mathrm{U}_{\mathrm{i}} \mathrm{N}_{\mathrm{i}}}{\mathrm{N}_{\mathrm{i}}} \\
\text { SAIDI } & =\frac{\sum((0,15 \times 65)+(0,15 \times 47)+. .+(15,03 \times 65))}{11764} \\
\text { SAIDI } & =7,567 \mathrm{jam} / \text { tahun }
\end{aligned}
$$

c. Customer Average Interruption Durtion index (CAIDI)

$$
\begin{aligned}
\text { CAIDI } & =\frac{\text { SAIDI }}{\text { SAIFI }} \\
& =\frac{7,567}{2,96228} \\
& =3,233 \text { jam/gangguan }
\end{aligned}
$$

d. Energy Not Supplied (ENS)

$$
\begin{aligned}
& \mathrm{ENS}=\sum \begin{array}{l}
L a(i) \cdot U i \\
\mathrm{ENS}
\end{array}=\sum \begin{array}{l}
41,65 \times 0,15+41,65 \times 0,15+\cdots+ \\
20,825 \times 15,00+41,65 \times 15,03
\end{array}
\end{aligned}
$$$$
\text { ENS }=35115,78557 \mathrm{KWh} / \text { tahun }
$$$$
\text { ENS }=35,11578 \mathrm{MWh} / \text { tahun }
$$

e. Average Energi Not Supplied (AENS)

$$
\text { AENS }=\frac{\text { ENS }}{\sum \text { LP }}
$$

Dimana:

ENS $\quad: 35,11578 \mathrm{MWh} /$ tahun

$\sum$ LP : 11764 titik beban

$$
\begin{aligned}
\text { AENS } & =\frac{35,11578}{11764} \\
& =0,0029 \mathrm{MWh} / \text { pelanggan }
\end{aligned}
$$

\subsection{Perhitungan Data Real di Lapangan}

Untuk menghitung indeks SAIFI, SAIDI, CAIDI, berdasarkan pemadaman yang terjadi dilapangan maka harus diketahui durasi pemadaman dan frekuensi pemadaman selama tahun 2016 pada penyulang MRA05. Data tersebut dapat dilihat pada tabel 10 berikut.

Tabel 10. Data Pemadaman PMT pada Penyulang MRA05

\begin{tabular}{clcc}
\hline No & \multicolumn{1}{c}{ Tanggal } & $\begin{array}{c}\text { Lama Padam } \\
\text { (jam) }\end{array}$ & $\begin{array}{c}\text { Pelanggan } \\
\text { Padam }\end{array}$ \\
\hline 1 & 11 januari 2016 & 5,28 & 11764 \\
2 & 13 januari 2016 & 3,23 & 11764 \\
3 & 04 februari 2016 & 2,25 & 11764 \\
4 & 01 maret 2016 & 3,58 & 11764 \\
5 & 10 maret 2016 & 3,23 & 11764 \\
6 & 01 april 2016 & 4,17 & 11764 \\
7 & 16 april 2016 & 0,65 & 11764 \\
8 & 11 juli 2016 & 1,47 & 11764 \\
9 & 15 juli 2016 & 2,53 & 11764 \\
10 & 26 juli 2016 & 1,63 & 11764 \\
11 & 05 september 2016 & 0,80 & 11764 \\
12 & 19 oktober 2016 & 3,67 & 11764 \\
13 & 25 oktober 2016 & 1,25 & 11764 \\
14 & 19 novemebr 2016 & 1,10 & 11764 \\
15 & 26 desember 2016 & 3,38 & 11764 \\
& TOTAL & 38,68 & \\
\hline
\end{tabular}

a. System Average Interruption Frequency Index (SAIFI)

$$
\begin{aligned}
& \text { SAIFI }=\frac{\sum \lambda_{\mathrm{i}} \mathrm{N}_{\mathrm{i}}}{\mathrm{N}_{\mathrm{i}}} \\
& \text { SAIFI }=\frac{\sum((1 \times 11764)+(1 \times 11764)+\cdots+(1 \times 11764))}{11764} \\
& \text { SAIFI }=15 \text { gangguan/tahun }
\end{aligned}
$$

b. System Average Interruption Duration Index (SAIDI)

$$
\begin{aligned}
\text { SAIDI } & =\frac{\sum \mathrm{U}_{\mathrm{i}} \mathrm{N}_{\mathrm{i}}}{\mathrm{N}_{\mathrm{i}}} \\
\text { SAIDI } & =\frac{\sum((5,28 \times 11764)+\cdots+(3,38 \times 11764))}{11764} \\
\text { SAIDI } & =38,68 \mathrm{jam} / \text { tahun }
\end{aligned}
$$

c. Customer Average Interruption Durtion index (CAIDI)

$$
\begin{aligned}
\text { CAIDI } & =\frac{\text { SAIDI }}{\text { SAIFI }} \\
& =\frac{38,68}{15} \\
& =2,5788 \text { jam/gangguan }
\end{aligned}
$$

Untuk menghitung indeks ENS,dan AENS berdasarkan pemadaman yang terjadi dilapangan maka harus diketahui besarnya daya yang tidak terkirim selama tahun 2016 
pada penyulang MRA05. Data tersebut dapat dilihat pada tabel 11 berikut.

Tabel 11. Data Pemadaman PMT pada Penyulang MRA05

\begin{tabular}{clcc}
\hline No & \multicolumn{1}{c}{ Tanggal } & $\begin{array}{c}\text { Lama Padam } \\
\text { (jam) }\end{array}$ & $\begin{array}{c}\text { Daya } \\
\text { Tersambung } \\
\text { (KW) }\end{array}$ \\
\hline 1 & 11 januari 2016 & 5,28 & 5147,94 \\
2 & 13 januari 2016 & 3,23 & 5147,94 \\
3 & 04 februari 2016 & 2,25 & 5147,94 \\
4 & 01 maret 2016 & 3,58 & 5147,94 \\
5 & 10 maret 2016 & 3,23 & 5147,94 \\
6 & 01 april 2016 & 4,17 & 5147,94 \\
7 & 16 april 2016 & 0,65 & 5147,94 \\
8 & 11 juli 2016 & 1,47 & 5147,94 \\
9 & 15 juli 2016 & 2,53 & 5147,94 \\
10 & 26 juli 2016 & 1,63 & 5147,94 \\
11 & 05 september 2016 & 0,80 & 5147,94 \\
12 & 19 oktober 2016 & 3,67 & 5147,94 \\
13 & 25 oktober 2016 & 1,25 & 5147,94 \\
14 & 19 novemebr 2016 & 1,10 & 5147,94 \\
15 & 26 desember 2016 & 3,38 & 5147,94 \\
& TOTAL & 38,68 & \\
\hline
\end{tabular}

d. Energy Not Supplied (ENS)

$$
\begin{aligned}
& \mathrm{ENS}=\sum L a(i) \cdot U i \\
& \mathrm{ENS}=\sum 5,28 x 5147,94+3,23 x 5147,94+\cdots+ \\
& 1,1 \times 5147,94+3,38 \times 5147,94
\end{aligned}
$$

ENS $=199139 \mathrm{KWh} /$ tahun

ENS $=199,139 \mathrm{MWh} /$ tahun

e. Average Energi Not Supplied (AENS)

AENS $=\frac{\text { ENS }}{\sum \text { LP }}$

Dimana:

ENS : 199,139 MWh/tahun

$\sum$ LP : 145 pelanggan

$$
\begin{aligned}
\text { AENS } & =\frac{199,139}{145} \\
& =1,373 \mathrm{MWh} / \text { pelanggan }
\end{aligned}
$$

\subsection{Perbandingan Hasil Perhitungan Metode RIA dengan Simulasi ETAP}

Tabel 12. Perbandingan Hasil Perhitungan Menggunakan Metode RIA dengan Simulasi ETAP

\begin{tabular}{lcc}
\hline \multicolumn{1}{c}{ Indeks Keandalan } & RIA & ETAP \\
\hline SAIFI (gangguan/tahun) & 2,96228 & 2,9635 \\
SAIDI (jam/tahun) & 9,1185 & 9,0286 \\
CAIDI (jam/gangguan) & 3,078 & 3,047 \\
ENS (MWh/tahun) & 42,1842 & 41,924 \\
AENS (MWh/pelanggan) & 0,00358 & 0,0029 \\
\hline
\end{tabular}

Dari tabel 12 diatas terlihat bahwa hasil perhitungan dengan menggunakan metode RIA sudah mendekati hasil simulasi pada ETAP, dimana nilai SAIFI menggunakan metode RIA sebesar 2,96228 gangguan/tahun sedangkan pada simulasi ETAP nilai SAIFI sebesar 2,9635 gangguan/tahun. Nilai SAIDI menggunakan metode RIA sebesar 9,1185 jam/tahun, sedangkan pada simulasi ETAP sebesar 9,0286 jam/tahun. Nilai CAIDI menggunakan metode RIA sebesar 3,078 jam/gangguan, sedangkan pada simulasi ETAP sebesar 3,047 jam/gangguan. Nilai ENS menggunakan metode RIA sebesar 42,1842 MWh/tahun, sedangkan pada simulasi ETAP sebesar 41,924 MWh/tahun. Nilai AENS menggunakan metode RIA sebesar 0,00358 MWh/pelanggan, sedangkan pada simulasi pada ETAP sebesar 0,0029 MWh/pelanggan. Dengan demikian dapat dikatakan bahwa hasil perhitungan dengan metode RIA dan simulasi ETAP sudah sesuai dengan teori dan persamaan yang digunakan, perbedaan yang terjadi karena adanya pembulatan pada simulasi ETAP.

\subsection{Perbandingan Hasil Perhitungan Menggunakan Metode RIA dan Simulasi saat DG Tidak Terpasang dengan Data Real di Lapangan}

Tabel 13. Perbandingan Hasil Perhitungan Menggunakan Metode RIA dan Simulasi ETAP dengan Data Real di Lapangan

\begin{tabular}{lccc}
\hline \multicolumn{1}{c}{ Indeks Keandalan } & RIA & ETAP & $\begin{array}{c}\text { Data } \\
\text { Lapangan }\end{array}$ \\
\hline SAIFI (gangguan/tahun) & 2,96228 & 2,9635 & 15 \\
SAIDI (jam/tahun) & 9,1185 & 9,0286 & 38,68 \\
CAIDI (jam/gangguan) & 3,078 & 3,047 & 2,5788 \\
ENS (MWh/tahun) & 42,1842 & 41,924 & 199,139 \\
AENS & 0,00358 & 0,0029 & 1,373 \\
(MWh/pelanggan) & & & \\
\hline
\end{tabular}

Dari tabel 13 dapat dilihat bahwa indeks keandalan hasil perhitungan data di lapangan memiliki perbedaan dibandingkan indeks keandalan hasil perhitungan menggunakan metode RIA dan hasil simulasi ETAP. Dimana nilai SAIFI menggunakan metode RIA sebesar 2,96228 gangguan/tahun, simulasi ETAP sebesar 2,9635 gangguan/tahun, sedangkan perhitungan data lapangan sebesar 15 gangguan/tahun. Nilai SAIDI menggunakan metode RIA sebesar 9,1185 jam/tahun, pada simulasi ETAP sebesar 9,0286 jam/tahun, sedangkan perhitungan data lapangan sebesar 38,68 jam/tahun. Nilai CAIDI menggunakan metode RIA sebesar 3,078 jam/gangguan, pada simulasi ETAP sebesar 3,047 jam/gangguan, sedangkan perhitungan data lapangan sebesar 2,5788 jam/gangguan. Nilai ENS menggunakan metode RIA sebesar 42,1842 MWh/tahun, pada simulasi ETAP sebesar 41,924 MWh/tahun, sedangkan perhitungan data lapangan sebesar 199,139 MWh/tahun . Nilai AENS menggunakan metode RIA sebesar 0,00358 MWh/pelanggan, simulasi pada ETAP sebesar 41,924 MWh/pelanggan, sedangkan perhitungan data lapangan sebesar 1,373 MWh/pelanggan. Perbedaan hasil perhitungan data lapangan dengan menggunakan metode RIA dan simulasi ETAP ini dikarenakan perhitungan data lapangan dilakukan dengan mengambil data berupa data pemadaman PMT dan tidak memperhitungkan laju kegagalan komponen pada penyulang MRA05. Selain itu 
penyebab dari pemadaman PMT sebagian besar disebabkan oleh faktor non teknis, seperti faktor alam, lingkungan, dan faktor non teknis lainnya.

\subsection{Perbandingan Perhitungan saat DG Tidak Terpasang dan Terpasang.}

Tabel 14. Perbandingan Hasil Perhitungan saat DG Tidak Terpasang dan Terpasang

\begin{tabular}{lcc}
\hline \multicolumn{1}{c}{ Indeks Keandalan } & $\begin{array}{c}\text { DG tidak } \\
\text { terpasang }\end{array}$ & $\begin{array}{c}\text { DG } \\
\text { terpasang }\end{array}$ \\
\hline SAIFI (gangguan/tahun) & 2,96228 & 2,96228 \\
SAIDI (jam/tahun) & 9,1185 & 7,567 \\
CAIDI (jam/gangguan) & 3,078 & 2,5546 \\
ENS (MWh/tahun) & 42,1842 & 35,11578 \\
AENS (MWh/pelanggan) & 0,00358 & 0,0029 \\
\hline
\end{tabular}

Dari tabel 14 diatas terlihat hasil simulasi indeks keandalan saat DG tidak terpasang dan terpasang. Dimana besarnya nilai SAIFI saat DG tidak terpasang sebesar 18,1156 gangguan/tahun, sedangkan saat DG terpasang sebesar 18,1156 gangguan/tahun, Nilai SAIDI saat DG tidak terpasang sebesar 58,5678 jam/tahun, saat DG terpasang sebesar 47,404 jam/tahun,. Nilai CAIDI saat DG tidak terpasang sebesar 3,233 jam/gangguan, saat DG terpasang sebesar 2,616 jam/gangguan,. Nilai ENS saat DG tidak terpasang sebesar 301,5035 MWh/tahun, saat DG terpasang sebesar 247,975 MWh/tahun. Nilai AENS saat DG tidak terpasang sebesar 2,0793 MWh/pelanggan, saat DG terpasang sebesar 1,710 MWh/tahun. Dari tabel 14 dapat disimpulkan bahwa dengan adanya DG yang terpasang dapat meningkatkan keandalan pada penyulang MRA05. Dapat dilihat dengan semakin kecilnya nilai indeks keandalan SAIDI, CAIDI, ENS dan AENS Sedangkan untuk besarnya nilai SAIFI tidak mengalami perubahan saat DG tidak terpasang dan terpasang, hal ini dikarenakan pada penyulang hanya terdapat satu buah PMT, sehingga dimanapun terjadi gangguan pada penyulang maka PMT akan trip. Dengan demikian maka hasil perhitungan sudah sesuai dengan teori yang ada

\subsection{Perbandingan SAIFI dan SAIDI Penyulang MRA05 dengan SPLN 68-2 Tahun 1986}

\section{Data real dan SPLN 68-2 1986}

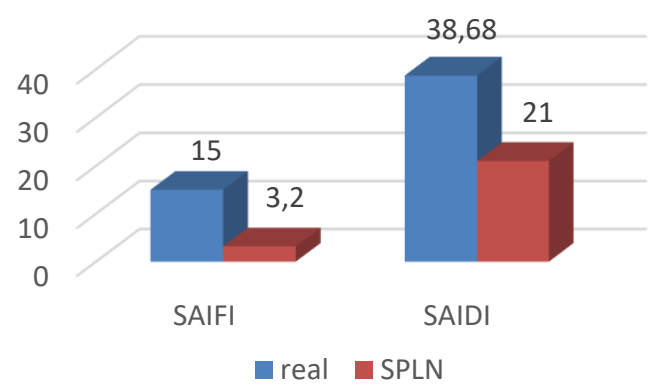

Gambar 5. Grafik perbandingan SAIFI dan SAIDI berdasarkan data real dan SPLN 68-2 1986
Dari gambar 5 terlihat bahwa nilai indeks keandalan SAIFI dan SAIDI berdasarkan data pemadaman tahun 2016 lebih besar daripada nilai SAIFI dan SAIDI berdasarkan SPLN, Hal ini berarti pada tahun 2016 penyulang MRA05 sering mengalami pemadaman dalam waktu yang relatif lama, sehingga dapat disimpulkan bahwa pada tahun 2016 penyulang MRA05 belum handal karena frekuensi pemadaman selama tahun 2016 melebihi standar indeks keandalan yang telah ditetapkan pada SPLN 68-2 1986.

\section{Kesimpulan}

Berdasarkan hasil perhitungan dan analisis yang telah dilakukan pada saat kondisi DG tidak terpasang dengan menggunakan metode Reliability Index Assesment (RIA), besarnya indeks keandalan pada penyulang MRA05 adalah SAIFI sebesar 2,96228 gangguan/tahun, SAIDI sebesar 9,1185 jam/tahun, CAIDI sebesar 3,078 jam/pelanggan, ENS sebesar 42,1842 MWh/tahun, AENS sebesar 0,00358 MWh/pelanggan. Pada kondisi DG terpasang dengan menggunakan metode Reliability Index Assesment (RIA), besarnya indeks keandalan pada penyulang MRA05 adalah SAIFI sebesar 2,9635 gangguan/tahun, SAIDI sebesar 7,567 jam/tahun, CAIDI sebesar 2,5546 jam/pelanggan, ENS sebesar 35,11578 MWh/tahun, AENS sebesar 0,0029 MWh/pelanggan.. Dengan demikian dapat disimpulkan bahwa dengan adanya DG yang terpasang dapat meningkatkan keandalan pada sistem, dibuktikan dengan lebih kecilnya nilai indeks keandalan SAIDI, CAIDI, ENS, dan AENS saat DG terpasang daripada saat DG tidak terpasang

\section{Referensi}

[1]. Chowdury, Ali A. dan Koval, Don O., Power Distribution System Reliability, John Wiley \& Sons Inc. Publication, New Jersey, 2009.

[2]. Ifanda, dkk. "Kajian Outage management Sistem Kelistrikan”.Serpong: Badan Pengkajian dan Penerapan teknologi (BPPT). 2014.

[3]. Billinton, Roy and Ronald N. Allan, Reliability Evaluation of Power Systems Second Edition, springer Science+Business Media, New York, 1996.

[4]. SPLN 68-2:1986. Tingkat jaminan sistem tenaga listrik.

[5]. Li, Fangxing. "Distributed Processing of Reliability Index Assesment and Reliability Based-Network Reconfiguration in Power distribution Systems'. IEEE Transactions on Power System, Vol.20,N0.1,2005

[6]. Willis, H. Lee and Scott Walter G. "Distributed Power Generation Planning and Evaluation", New York, 2000.

[7]. Sabpayakom Noppatee and Somporn Sirisumrannukul "Power Losses reduction and reliability improvement in distribution system with Very Small Power Producers" 3rd internatioanal Conference on Power and Energy Systems Engineering, CPESE 2016, Kitakyushu, Japan, September 2016.

[8]. SPLN $59: 1985$. Keandalan pada Sistem Distrbusi 20 $k V$ dan $6 k V$ 